\title{
Air quality change during the COVID-19 pandemic lockdown over the Auvergne-Rhône-Alpes region, France
}

\author{
Salah Eddine Sbai ${ }^{1}$ (D) Nezha Mejjad ${ }^{2} \cdot$ Abderrahim Norelyaqine $^{3} \cdot$ Farida Bentayeb $^{1}$ \\ Received: 29 August 2020 / Accepted: 4 November 2020 / Published online: 19 January 2021 \\ (C) Springer Nature B.V. 2021
}

\begin{abstract}
Under the rapid spread of coronavirus diseases (COVID-19) worldwide, a complete lockdown was imposed in France from March 17th to May 11th, 2020 to limit the virus spread. This lockdown affected significantly the atmospheric pollution levels due to the restrictions of human activities. In the present study, we investigate the evolution of air quality in the Auvergne-RhôneAlpes region, focusing on nine atmospheric pollutants $\left(\mathrm{NO}_{2}, \mathrm{NO}, \mathrm{PM}_{10}, \mathrm{PM}_{2.5}, \mathrm{O}_{3}, \mathrm{VOC}, \mathrm{CO}, \mathrm{SO}_{2}\right.$, and isoprene). In Lyon, center of the region, the results indicated that $\mathrm{NO}_{2}, \mathrm{NO}$, and $\mathrm{CO}$ levels were reduced by $67 \%, 78 \%$, and $62 \%$, respectively, resulting in a decrease in road traffic by $80 \%$. However, $\mathrm{O}_{3}, \mathrm{PM}_{10}$, and $\mathrm{PM}_{2.5}$ were increased by $105 \%, 23 \%$, and $53 \%$, respectively, during the lockdown. The increase in ozone is explained by the dropping in NO and other gases linked to human activity, which consume ozone. Thus, the increase of solar radiation, sunshine, temperature, and humidity promoted the $\mathrm{O}_{3}$ formation during the lockdown. Besides, rising temperature enhances the BVOC emissions such as isoprene. In addition, volatile organic component (VOC) and $\mathrm{SO}_{2}$ remain almost stable and oxidation of these species leads to the formation of ozone and organic aerosol, which also explains the increase in PM during the lockdown. This study shows the contribution of atmospheric photochemistry to air pollution.
\end{abstract}

Keywords COVID-19 $\cdot$ Air quality index $\cdot$ Pollution $\cdot$ Lockdown $\cdot$ Auvergne-Rhône-Alpes $\cdot$ Lyon

\section{Introduction}

The new coronavirus discovered in Wuhan in China in late December 2019 has spread easily and sustainably. This infectious virus has caused many effects in almost all countries around the world. Because of the high propagation rate of COVID-19 between people, several countries have taken measures of safety to limit the spread of the virus. Accordingly, several human activities were suspended including industrial activities, tourism, and transport, while all scientific and cultural meetings were postponed across the globe. On 15th June the number of

Salah Eddine Sbai

salaheddinechimie@gmail.com

1 Department of physics, Laboratoires de physique des hauts Energies Modélisation et Simulation, Mohammed V University in Rabat, Rabat, Morocco

2 Department of Geology, Faculty of Sciences, Ben M'Sik Hassan II University, Casablanca, Morocco

3 Mohammedia School of Engineers, Mohammed V. University in Rabat, Rabat, Morocco
COVID-19 confirmed cases in Italy has reached 236,989; in Spain 243,928; in The UK 295,893; in India 332,424; in the USA 2,057,838; in Brazil 850,514; and in France 152,767 (WHO 2020).

The coronavirus disease has reached France on 24, January 2020 and the first imported cases in Europe were also detected in France (Bernard et al. 2020). The number of confirmed cases was progressively increased which lead to the announcement of limited safety measures on February 28th. While on March 17th, 2020, the French authority has implemented a nationwide lockdown as a response to the rapid spread of COVID-19 (Pullano et al. 2020). These strict safety measures have impacted negatively almost all economic activities in the whole world. In contrast, the environment has taken advantage of lockdown as the activities generating pollutants were reduced or suspended such as industrial activities, local transport and travel in and out the home country, and population mobility (Lal et al. 2020). Accordingly, several studies were carried out to evaluate the impact of imposed lockdown on the environment (Agarwa et al. 2020; Mandal and Pal 2020; Kerimray et al. 2020; He et al. 2020a, b; Bao and Zhang 2020; Zhu et al. 2020; Yao et al. 2020; Chu et al. 2020; Shakoor et al. 2020; Gautam 2020; Pata 2020). 
The present study investigates the impact of imposed lockdown on air quality using the main atmospheric pollutants including the nitrogen dioxide $\left(\mathrm{NO}_{2}\right)$, ozone $\left(\mathrm{O}_{3}\right)$, particulate matter $\left(\mathrm{PM}_{2.5}\right.$ and $\left.\mathrm{PM}_{10}\right)$, volatile organic component (VOC), sulfur dioxide $\left(\mathrm{SO}_{2}\right)$, and carbon monoxide $(\mathrm{CO})$, retrieved from 79 air quality monitoring stations of Auvergne-RhôneAlpes region, France. This will allow identifying the principal sources of pollution and helping regulators to set pollution reduction targets at a level that would minimize the risk to the health of the exposed population. This study was focused more precisely on Lyon city (center of Auvergne-RhôneAlpes region), as it is considered to be the most urbanized area with a high vehicle density (Anzivino and Venzac 2018) and which was largely affected by air pollution.

\section{Methodology}

\section{Study area}

Auvergne-Rhône-Alpes region is one of the most populated regions in Europe and the leading French industrial region. It is characterized by high population density and the large expansion of its territory combining large agglomerations of 5 metropolises: Lyon (1,622,331; region prefecture), Grenoble $(510,368)$, Saint-Etienne $(372,308)$, Clermont-Ferrant $(264,704)$, and Chambéry $(186,355)$, and 12 departments namely: Ain, Allier, Ardèche, Cantal, Drôme, Isère, Loire, Haute-Loire, Puy-de-Dôme, Rhône, Savoie, and HauteSavoie (Fig. S1). It is located in the southeastern quarter of France, bordering on Switzerland and Italy. Auvergne-RhôneAlpes occupies an area about $69,711 \mathrm{~km}^{2}$, and a population of $8,037,059$ inhabitants, with a density of 115 inhabitants $/ \mathrm{km}^{2}$. It is bordered by five other administrative regions: Bourgogne-Franche-Comté to the north, Centre-Val de Loire to the northeast, Nouvelle-Aquitaine to the west, Occitanic to the south-west, and Provence-Alpes-Côte d'Azur to the southeast. It is also bordered by Italy (Aosta Valley and Piedmont) to the east and Switzerland (Cantons of Geneva, Valais, and Vaud) to the north-east.

The average annual temperatures for this region are ranged from 5 to $15{ }^{\circ} \mathrm{C}$, while the highest average annual temperatures are characterizing the south part of the region, which is under the Mediterranean influence. Auvergne Rhône-Alpes region is the sunniest French region (1976 h/year), it is characterized by very variable climate, the summers are pretty hot and quite humid because of some Mediterranean influences. Besides, the winters are very cold due to the presence of the mountains and dry in the south. Because of the different climates around the region, the vegetation is miscellaneous, there are numerous regional and national parks and lush forests but also southerner plants.

\section{Pollution data sources}

The data covering the whole area of the Auvergne-RhôneAlpes region were analyzed, in terms of mass concentration of the different pollutants between 3rd February and 15th June 2020. The daily average mass concentrations of several air pollutants, including nitrogen oxides $\left(\mathrm{NOx}, \mathrm{NO}\right.$, and $\left.\mathrm{NO}_{2}\right)$, sulfur dioxide $\left(\mathrm{SO}_{2}\right)$, particulate matter $\left(\mathrm{PM}_{2.5}\right.$ and $\left.\mathrm{PM}_{10}\right)$, carbone monoxide $(\mathrm{CO})$, ozone $\left(\mathrm{O}_{3}\right)(8 \mathrm{~h}$ diurnal average, from 08:00 AM until 16:00 PM), and volatile organic component (VOC) from 79 monitoring stations spread over the region were extracted and used (Fig. S1). Data used in the present study is available in Atmo-Auvergne-Rhône-Alpes online portal for air quality data dissemination (Atmo 2020a).

\section{Meteorological conditions}

The meteorological conditions strongly influence the formation and the evolution of many atmospheric pollutants (Zhang 2019; Chen et al. 2020a, b). Meteorological conditions data used in the present study including maximum and minimum temperatures, relative humidity, wind speeds, solar radiation, sunshine duration, and rainfall, for the period extending from 3rd February to 15th June in the Lyon, were downloaded from the weather station of Lyon-Bron (Info climat 2020).

\section{Meteorological parameters influencing air pollution}

The wind is a fundamental element for the dispersion, dilution, and orientation of pollutant plumes. Under high wind speed, the dispersion of the pollutant is greater, while, in the lower wind speed is likely for air pollution accumulation. Strong winds can direct a plume to a specific area, thereby concentrating pollution. Rain cleans the atmosphere from several pollutants because the falling water interacts with the pollutants present during its fall and then transform or deposit them on the ground. For nitrogen oxides, leaching is an efficient phenomenon permitting the decrease of NOx concentrations; however, chemical interaction between $\mathrm{NO}_{2}$ and water leads to the formation of acid rain. Likewise, the particle matter (PM) can be cleaned from the air by the rain. Concerning ozone, despite his very low soluble in water, leaching contributes also to reduce its concentrations. Both high and low temperatures influenced the air atmospheric pollution emissions, formation, and evolution, for example, the volatility of organic species like VOC increase with temperature, which may increase their ratio in the gas phase and thus their condensation and conversion especially into particles (Kourtchev et al. 2016). Sunshine duration, solar radiation, and relative humidity $(\mathrm{RH})$ can strongly affect atmospheric photochemistry such as $\mathrm{O}_{3}$ and $\mathrm{OH}$ radical formation, and also particle process formation including nucleation, condensation, and growth (Li et al. 2018; Lu et al. 2019a, b). 


\section{Results and discussion}

\section{The normal situation of $\mathrm{NO}_{2}, \mathrm{O}_{3}, \mathrm{PM}_{10}$, and $\mathrm{PM}_{2.5}$ mass concentration over Auvergne-Rhône-Alpes region}

Figure 1 shows the mapping of the normal situation of $\mathrm{NO}_{2}$, $\mathrm{O}_{3}, \mathrm{PM}_{10}$, and $\mathrm{PM}_{2.5}$ mass concentration distribution over Auvergne-Rhône-Alpes. The highest $\mathrm{NO}_{2}, \mathrm{PM}_{2.5}$, and $\mathrm{PM}_{10}$ levels are recorded in the middle at Rhône and Loire departments, which are characterized by high population and car densities (Anzivino and Venzac 2018). Nevertheless, only $\mathrm{NO}_{2}$ levels exceed European limit values $\left(40 \mu \mathrm{g} / \mathrm{m}^{3}\right)$, especially in Rhône and Loire departments and in the north of the Ain department. The industrial activities located in the south of the Lyon metropolis contribute significantly to the increase in PM level, either by direct emissions or by VOC conversion via photochemical reactions (Kourtchev et al. 2016; Palm et al. 2016; Sbai et al. 2020). Thus, sulfate particles can represent a significant amount of PM in the center of the region due to the $\mathrm{SO}_{2}$ emission by industrial activities located in several areas in the Rhône department (Fig. S2). The moderate ozone mass concentration observed in Rhône and Loire departments can be especially due to its consumption by $\mathrm{NO}_{2}$ because this area is characterized by high levels of $\mathrm{NO}_{2}$ (Fig. 1). The departments affected by the highest $\mathrm{O}_{3}$ mass concentration are Allier, Cantal, and Puy de Dôme; they are characterized by low population and car density. Moreover, higher solar radiation and sunshine in this area promote the formation of ozone $\left(\mathrm{O}_{3}\right)$, but stay below European Limit values $(120 \mu \mathrm{g} /$ $\mathrm{m}^{3}$ daily $8 \mathrm{~h}$ mean) (European Commission 2019).

\section{Spatial changes for main air pollutions $\left(\mathrm{NO}_{2}, \mathrm{O}_{3}\right.$, $\mathbf{P M}_{2.5}$, and $\mathbf{P M}_{10}$ ) affecting the air quality during COVID-19 pandemic lockdown}

\section{Spatial pattern of nitrogen oxides $\left(\mathrm{NO}_{2}\right)$ mass concentration}

The $\mathrm{NO}_{2}$ mass concentration before, during, and after lockdown is presented in a form of maps in Fig. 2. The
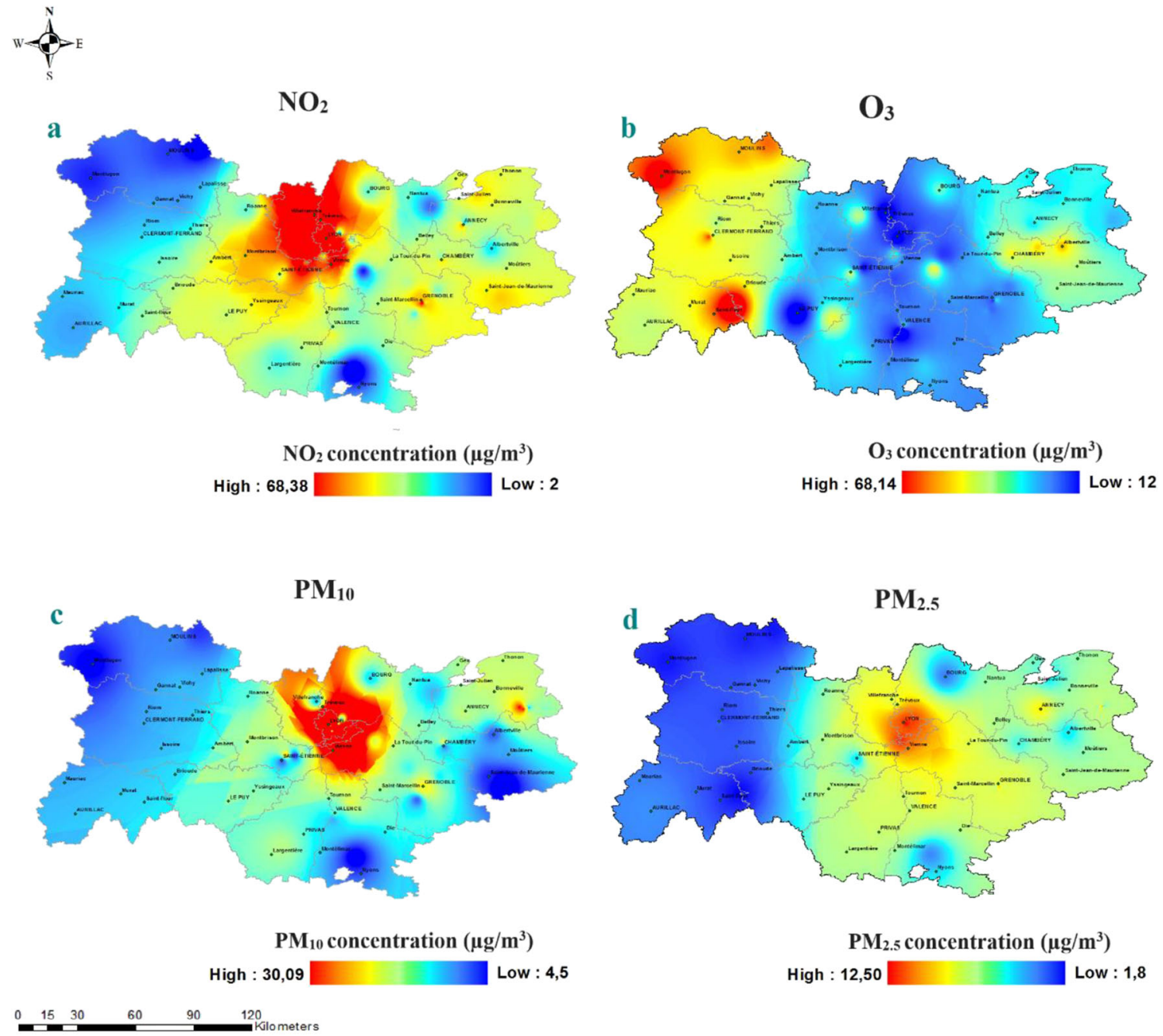

Fig. 1 Normal spatial distribution for $\mathrm{NO}_{2}, \mathrm{O}_{3}$, PM10, and PM2.5 mass concentrations for March 10th, 2020 
10 MARCH

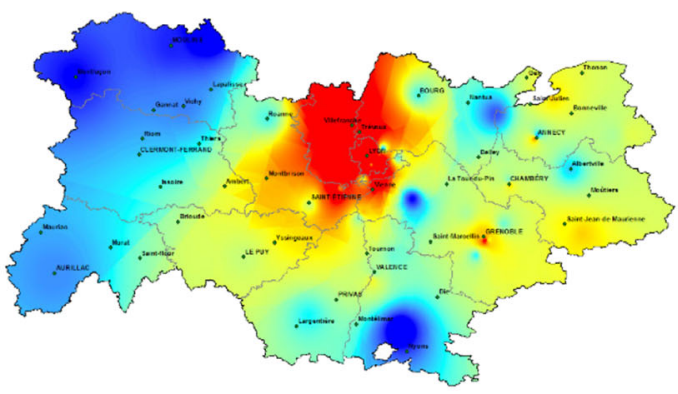

19 MARCH

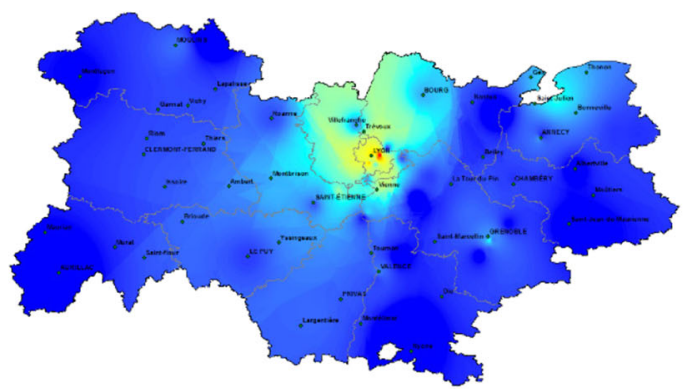

18 MAY

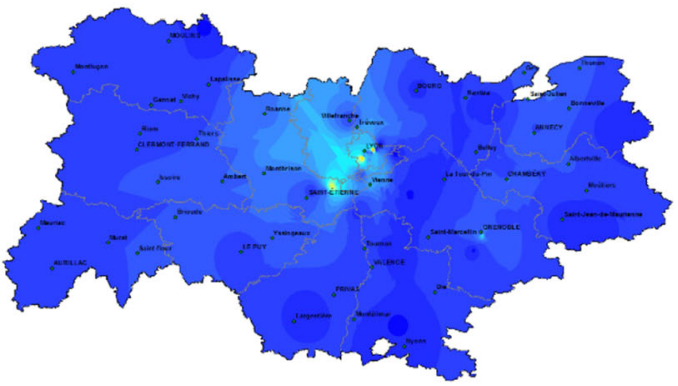

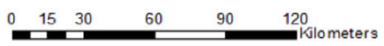

17 MARCH

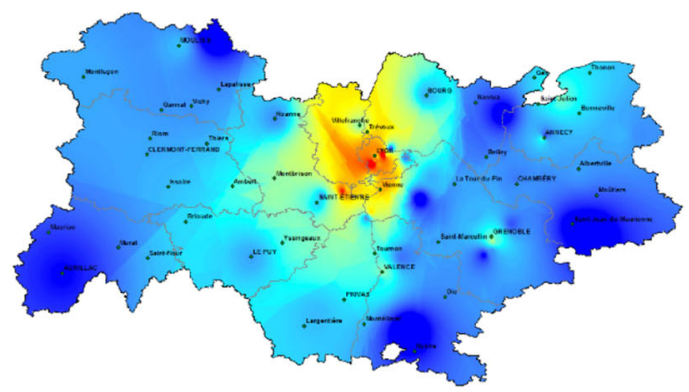

24 MARCH

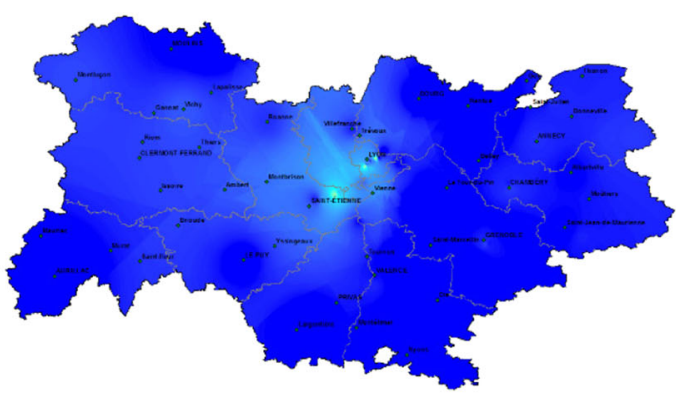

27 MAY

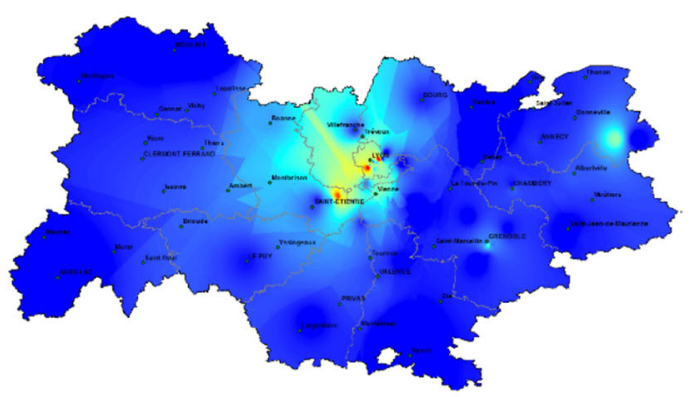

$\mathrm{NO}_{2}$ concentration $\left(\mu \mathrm{g} / \mathrm{m}^{3}\right)$

High : 73,8 Low : 0,5

Fig. 2 Spatial distribution for $\mathrm{NO}_{2}$ mass concentrations before (March 10th), during (March 17th, 19th, and 26 th), and after lockdown (May 18th and 27th)

reduction of road activities during lockdown reached $80 \%$ in the Auvergne-Rhône-Alpes region (Fig. S3); hence, atmospheric level of $\mathrm{NO}_{2}$ may be affected. On March 10th, the $\mathrm{NO}_{2}$ mass concentrations were high in the center (Rhône and Loire departments) and medium in the west of the region. Since the lockdown was implemented by the French authority on March 17th, 2020 (Pullano et al. 2020), the $\mathrm{NO}_{2}$ level has decreased by $67.9 \%$ (at Saint Etienne) and $53.6 \%$ (at Annecy) during the lockdown (Table 1), because almost all the human activities were halted except power generation. It is also noticed that the $\mathrm{NO}_{2}$ levels tend to increase, which is due to the beginning of easing the imposed lockdown restrictions on 11th and May 27th. Thus, these results indicate the improvement in air quality and prove that human activities are the main source for nitrogen dioxide rather than natural events and that lockdown some time will be mandatory to reduce pollution and improve air quality.

Several studies were carried out around the worldwide cities and have provided the positive impact of enforced lockdown as a response to the COVID-19 outbreak on air quality. In 44 cities located in the northern part of China, the $\mathrm{NO}_{2}$ values were decreased by $24.7 \%$ because of the drop in human mobility by $69.8 \%$ and suspension of industrial activities (Bao 
Table 1 Summary of air pollution concentrations before and during COVID-19 pandemic for nitrogen dioxide $\left(\mathrm{NO}_{2}\right)$, particulate matter $\left(\mathrm{PM}_{2.5}\right.$ and $\left.\mathrm{PM}_{10}\right)$, and ozone $\left(\mathrm{O}_{3}\right)$ for main cities in the region

\begin{tabular}{|c|c|c|c|c|c|}
\hline \multirow[t]{2}{*}{ Pollutant } & \multirow[t]{2}{*}{ Cities } & \multirow[t]{2}{*}{ Station } & \multicolumn{2}{|c|}{ Average mass concentration $\left(\mu \mathrm{g} / \mathrm{m}^{3}\right)$} & \multirow[t]{2}{*}{ Difference $(\%)$} \\
\hline & & & Before lockdown $^{\mathrm{a}}$ & During lockdown ${ }^{\mathrm{b}}$ & \\
\hline \multirow[t]{6}{*}{$\mathrm{NO}_{2}$} & Lyon & Lyon center & 36.8 & 12.0 & -67.4 \\
\hline & Grenoble & Grenoble les Frenes & 28.0 & 10.6 & -62.1 \\
\hline & Saint Etienne & Saint-Martin d'Heres & 34.0 & 10.9 & -67.9 \\
\hline & Annecy & Annecy Loverchy & 27.4 & 12.7 & -53.6 \\
\hline & Chambery & Chambéry Pasteur & 28.4 & 11.3 & -60.2 \\
\hline & Valence & Valence urbain center & 26.1 & 9.3 & -64.4 \\
\hline \multirow[t]{6}{*}{$\mathrm{PM}_{2.5}$} & Lyon & Lyon center & 12.1 & 18.5 & 52.9 \\
\hline & Grenoble & Grenoble les Frenes & 12.5 & 13.4 & 32.8 \\
\hline & Saint Etienne & Saint-Martin d'Heres & 11.6 & 15.7 & 35.3 \\
\hline & Annecy & Annecy Loverchy & 9.4 & 11.8 & 20.7 \\
\hline & Chambery & Chambéry Pasteur & 6.7 & 13.2 & 97 \\
\hline & Valence & Valence urbain center & 11.6 & 15.4 & 32.8 \\
\hline \multirow[t]{6}{*}{$\mathrm{PM}_{10}$} & Lyon & Lyon center & 20.0 & 24.5 & 22.5 \\
\hline & Grenoble & Grenoble les Frenes & 17.5 & 20.1 & 14.9 \\
\hline & Saint Etienne & Saint-Martin d'Heres & 20.0 & 20.9 & 4.5 \\
\hline & Annecy & Annecy Loverchy & 18.6 & 20.7 & 11.3 \\
\hline & Chambery & Chambéry Pasteur & 9.8 & 17.4 & 77.6 \\
\hline & Valence & Valence urbain center & 16.6 & 20.7 & 24.7 \\
\hline \multirow[t]{6}{*}{$\mathrm{O}_{3}$} & Lyon & Lyon center & 33.5 & 68.9 & 105.7 \\
\hline & Grenoble & Grenoble les Frenes & 30.3 & 61.4 & 102.6 \\
\hline & Saint Etienne & Saint-Martin d'Heres & 27.9 & 61.6 & 120.7 \\
\hline & Annecy & Annecy Loverchy & 31.6 & 66.2 & 109.5 \\
\hline & Chambery & Chambéry Pasteur & 32.4 & 63.0 & 94.4 \\
\hline & Valence & Valence urbain center & 37.8 & 66.5 & 75.9 \\
\hline
\end{tabular}

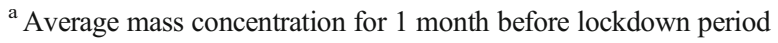

${ }^{\mathrm{b}}$ Average mass concentration during lockdown period before consecutive rainy days

and Zhang 2020). The same case is observed in Almaty (Kazakhstan), where the $\mathrm{NO}_{2}$ levels were reduced by $35 \%$ (Kerimray et al. 2020) while in Barcelona (Spain), it was reduced by half during the lockdown period (Tobías et al. 2020). In the whole world, the restriction of human activities has led to an apparent reduction of nitrogen dioxide (Dantas et al. 2020; Bao and Zhang 2020; Ogen 2020).

\section{Spatial pattern of ozone mass concentration}

Figure 3 represents the spatial evolution of the ozone mass concentration over the Auvergne-Rhône-Alpes region from March 10th to May 27th, 2020. The results indicate an increase of $\mathrm{O}_{3}$ levels from the beginning of the lockdown (March 17th) and this increase has become clearer on May 18th, especially in the center and south of
Auvergne-Rhône-Alpes region. The results show that ozone mass concentration increased by 120.7, 109.5, 105.7, 102.6, 94.4, and 75.9\% in Saint Etienne, Annecy, Lyon, Grenoble, Chambery, and Valence, respectively (Table 1). This behavior could be attributed to the drastic drop in NO levels (Fig. S4), which leads to the reduction of the $\mathrm{O}_{3}$ consumption (Sharma et al. 2020). The ozone destruction flux via the main $\mathrm{NO}_{\mathrm{X}}$ photochemical reactions has been calculated (Table 2); the flux has been reduced from $1.51 \times 10^{23}$ (molecule $\mathrm{cm}^{-3} \mathrm{~s}^{-1}$ ) before the lockdown to $6.28 \times 10^{22}$ (molecule $\mathrm{cm}^{-3} \mathrm{~s}^{-1}$ ) during the lockdown, which represent a reduction of $40 \%$ of $\mathrm{O}_{3}$ destruction. This partially explains the increase in ozone during the lockdown. Similar results were found in almost all studies done in worldwide cities (Mahato et al. 2020; Siciliano et al. 2020). Besides, the significant ozone levels 
10 MARCH

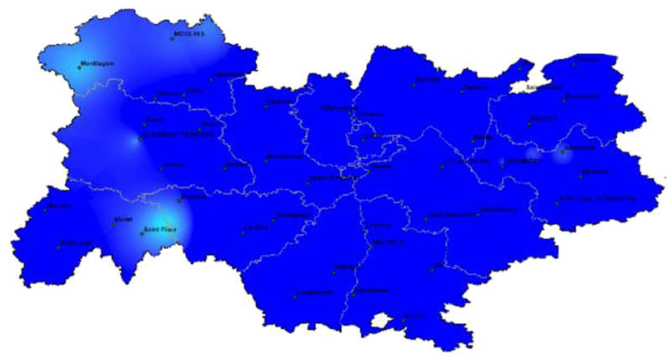

19 MARCH

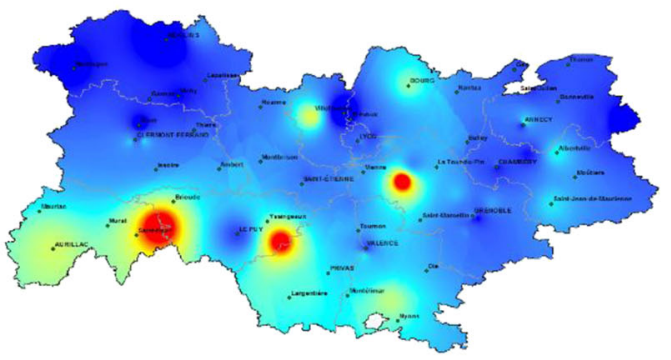

18 MAY

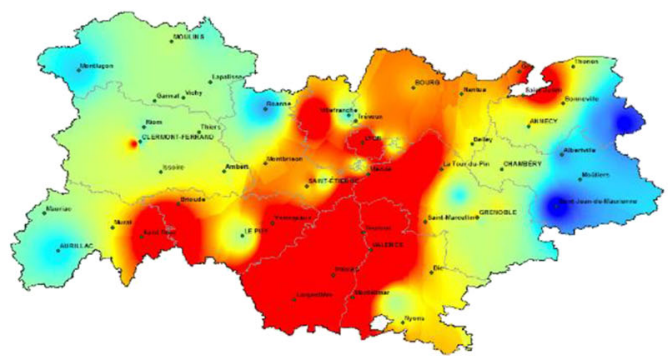

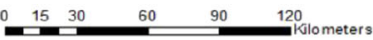

17 MARCH

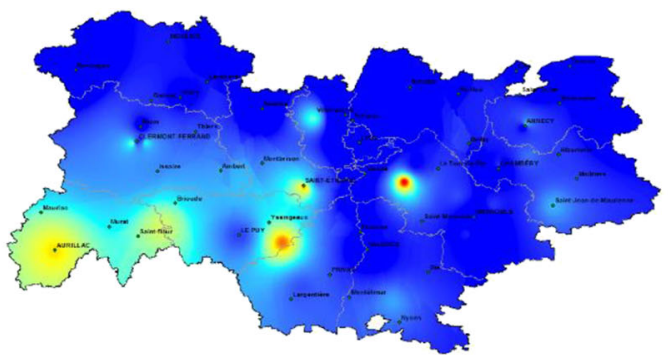

26 MARCH

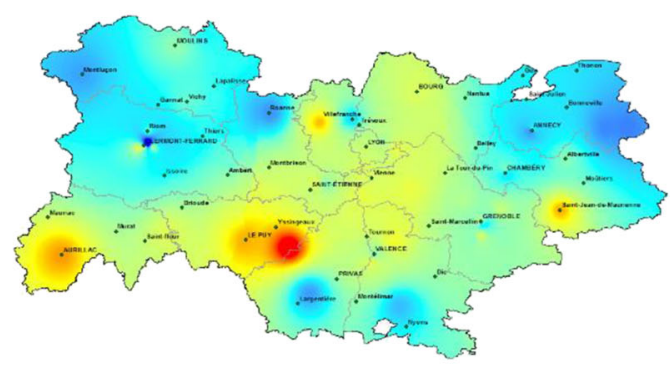

27 MAY

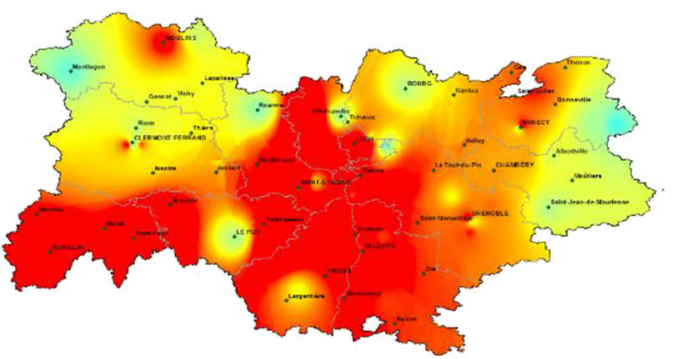

OZONE concentration $\left(\mu \mathrm{g} / \mathrm{m}^{3}\right)$

High : 112,11 Low : 12

Fig. 3 Spatial distribution for $\mathrm{O}_{3}$ mass concentrations before (March 10th), during (March 17th, 19th, and 26th), and after lockdown (May 18th and 27th)

detected in rural areas can be explained by the transport of air masses over long distances from urban areas. In addition, the presence of methane $\left(\mathrm{CH}_{4}\right)$, an important ozone precursor with a long chemical lifetime (about 9 years), contributes significantly to $\mathrm{O}_{3}$ formation in rural areas (Atmo 2020b).

Table 2 Ozone production and depletion flux via NOx photochemical reactions under low an high NOx levels

\begin{tabular}{llll}
\hline Reaction & Rate constant (molecule $\left.\mathrm{cm}^{3} \mathrm{~s}^{-1}\right)$ & \multicolumn{2}{l}{ Flux (molecule $\mathrm{cm}^{-3} \mathrm{~s}^{-1}$ ) } \\
\cline { 3 - 4 } & & Befor lockdown (high NOx level) & After lockdown (low NOx level) \\
\hline $\mathrm{NO}_{2}+\mathrm{hv} \geq \mathrm{NO}+\mathrm{O}\left({ }^{3} \mathrm{P}\right)$ & $5.0 \times 10^{-3}$ & $3.28 \times 10^{9}$ & $6.05 \times 10^{8}$ \\
$\mathrm{O}\left({ }^{3} \mathrm{p}\right)+\mathrm{O}_{2} \geq \mathrm{O}_{3}$ & $1.5 \times 10^{-14}$ & $4.04 \times 10^{12}$ & $4.04 \times 10^{12}$ \\
$\mathrm{NO}+\mathrm{O}_{3} \geq \mathrm{NO}_{2}+\mathrm{O}_{2}$ & $2.0 \times 10^{-14}$ & $1.51 \times 10^{23}$ & $6.28 \times 10^{22}$ \\
$\mathrm{NO}_{2}+\mathrm{O}_{3} \geq \mathrm{NO}_{3}+\mathrm{O}_{2}$ & $3.2 \times 10^{-17}$ & $8.05 \times 10^{-6}$ & $4.03 \times 10^{-6}$ \\
$\mathrm{Net}_{\text {flux }}$ & - & $1.51 \times 10^{23}$ & $6.28 \times 10^{22}$ \\
\hline
\end{tabular}




\section{Spatial pattern of particulate matter $\mathrm{PM}_{10}$ and $\mathrm{PM}_{2.5}$ mass concentration}

Figures 4 and S5 show the spatial distribution of $\mathrm{PM}_{2.5}$ and $\mathrm{PM}_{10}$ mass concentrations. Conversely to the most pollutants, the $\mathrm{PM}_{2.5}$ and $\mathrm{PM}_{10}$ have increased during the lockdown and show the same trend while the lower concentrations were registered on March 10th (before lockdown), May 18th and 27th (after lockdown), and the higher levels were recorded during the lockdown on March 17th, 19th, and 26th. The results show also that the $\mathrm{PM}_{2.5}$ mass concentration increased by $97,52.9,35.3,32.8$, and $20.7 \%$ in Chambery, Lyon, Saint Etienne, (Grenoble and Valence), and Annecy, respectively. Furthermore, the $\mathrm{PM}_{10}$ mass concentration increased by 77.6,

\section{MARCH}

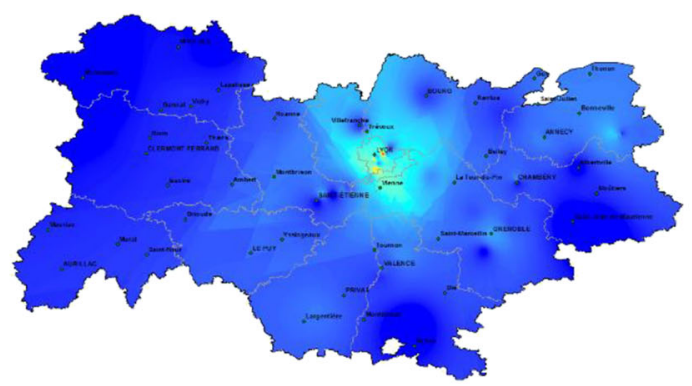

19 MARCH

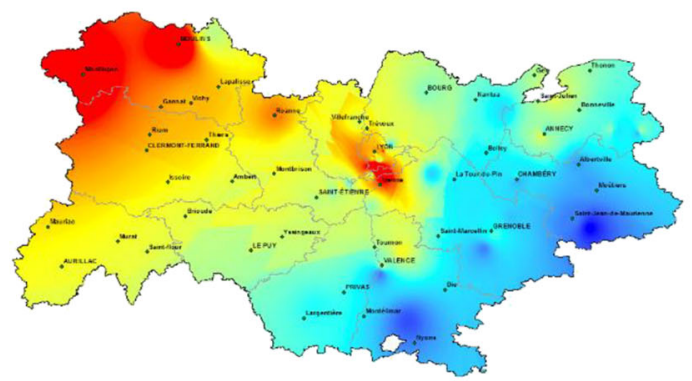

18 MAY
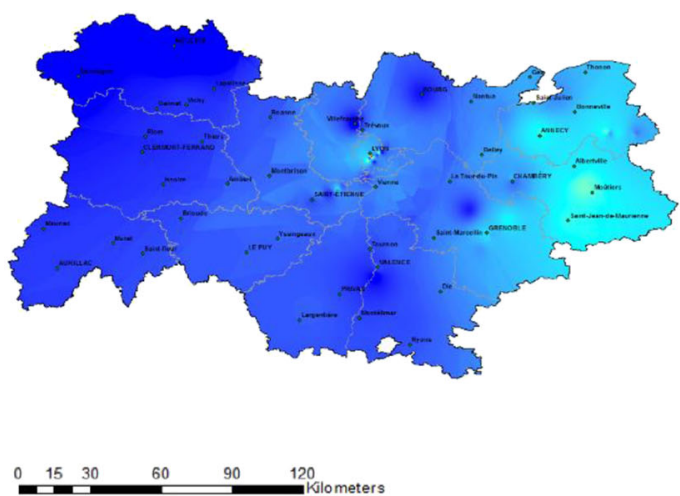

24.7, 22.5, 14.9, 11.3, and 4.5\% in Chambery, Valence, Lyon, Grenoble, Annecy, and Saint Etienne, respectively (Table 1).

Residential wood heating which is the main emitter of $\mathrm{PM}_{10}$ and $\mathrm{PM}_{2.5}$ in cold weather can contribute to $80 \%$ of total particle emissions in this region (Atmo 2020c). Thus, domestic housing could contribute to emissions of PM during the lockdown where the people spent more time confined in their homes, which increases the consumption of wood heating and consequently much PM emission. In addition to primary sources (heating, vehicles exhaust, and industrial activities), numerous secondary sources can also contribute to the PM emission, such as the atmospheric photochemistry (Ortega et al. 2016; Huang et al. 2015; Sbai and Farida 2019a). The SOA formation is enhanced during the lockdown period

\section{MARCH}

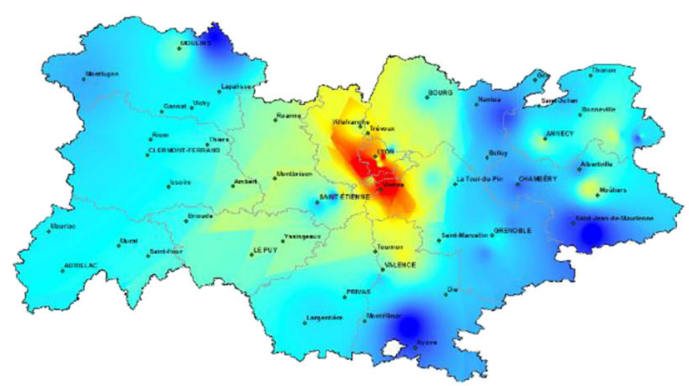

26 MARCH

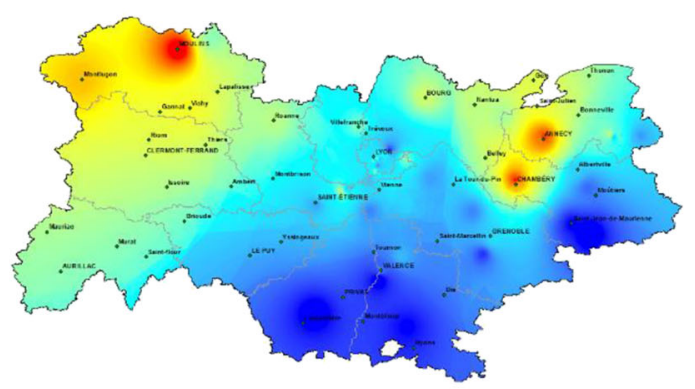

27 MAY

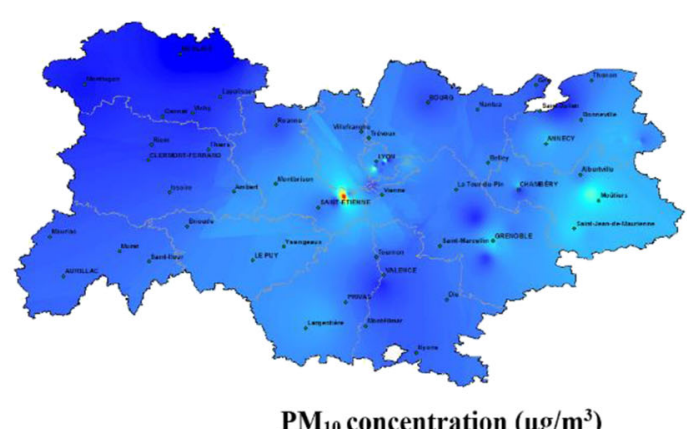

$\mathbf{P M}_{10}$ concentration $\left(\mu \mathrm{g} / \mathrm{m}^{3}\right)$

High : 51,9 Low : 1

Fig. 4 Spatial distribution for PM10 mass concentrations before (March 10th), during (March 17th, 19th, and 26th), and after lockdown (May 18th and 27 th) 
because of the increase in $\mathrm{O}_{3}$ that can produce the $\mathrm{OH}$ radical in the presence of humidity, according to the two reactions $\mathrm{O}_{3}+\mathrm{hv} \rightarrow \mathrm{O}_{2}+\mathrm{O}\left({ }^{1} \mathrm{D}\right)$ and $\mathrm{O}\left({ }^{1} \mathrm{D}\right)+\mathrm{H}_{2} \mathrm{O} \rightarrow 2 \mathrm{OH}$ (Peng et al. 2015).

In the Rhône department, which is characterized by high levels of $\mathrm{PM}_{10}$ and $\mathrm{PM}_{2.5}$ (Figs. 4 and S5), industrial activities were not significantly affected by lockdown, since VOC levels in three areas of this region (Fayzin ZI, Saint-Fons ZI, and Vernaison ZI) remain almost stable (Fig. 5e). This clearly shows that $\mathrm{O}_{3} / \mathrm{OH}$ oxidation of VOCs is an important secondary source of $\mathrm{PM}_{10}$ and $\mathrm{PM}_{2.5}$ in the metropolitan Lyon. In addition, in the Auvergne-Rhône-Alpes region, there are several parks and important forest areas (Fibois 2018), which may represent an important source of biogenic VOCs (BVOC), which can contribute to the PM formation. In our previous study, we found that urban air in Lyon can effectively contribute to the SOA formation via $\mathrm{OH}$ oxidation and ozonolysis (Sbai et al. 2020). Moreover, Sea salt especially iodine can contribute also to $\mathrm{PM}$ formation via $\mathrm{OH}$ and $\mathrm{O}_{3}$ oxidation mainly under high $\mathrm{O}_{3}$ levels (Saiz-Lopez and Plane 2004; Gómez Martín et al. 2013; Sbai and Farida 2019b). These particles could be transported by the wind towards the urban environment during the lockdown.

These results indicate that this region has experienced spatial $\mathrm{PM}_{10}$ and $\mathrm{PM}_{2.5}$ level increase during the lockdown period, in contrast to the similar studies carried out in other cities around the world where the $\mathrm{PM}_{2.5}$ and $\mathrm{PM}_{10}$ levels were declined during the enforced lockdown (Chauhan and Singh 2020; Dantas et al. 2020; Zambrano-Monserrate et al. 2020).

The evolution of air pollutions $\left(\mathrm{PM}_{10}, \mathrm{PM}_{2.5}, \mathrm{NO}_{2}, \mathrm{O}_{3}\right.$, $\mathrm{CO}$, and $\mathrm{VOC}$ ) affecting the air quality in Lyon

Figure 5 summarizes the evolution of the $\mathrm{PM}_{10}, \mathrm{PM}_{2.5}, \mathrm{NO}_{2}$, $\mathrm{O}_{3}$, CO, and VOC in Lyon (center of the Auvergne-RhôneAlpes region) between February 3rd and June 15th, 2020, to assess the effects of lockdown on air quality. We noticed a strong decrease in $\mathrm{NO}_{2}$ during the first 2 weeks of lockdown.
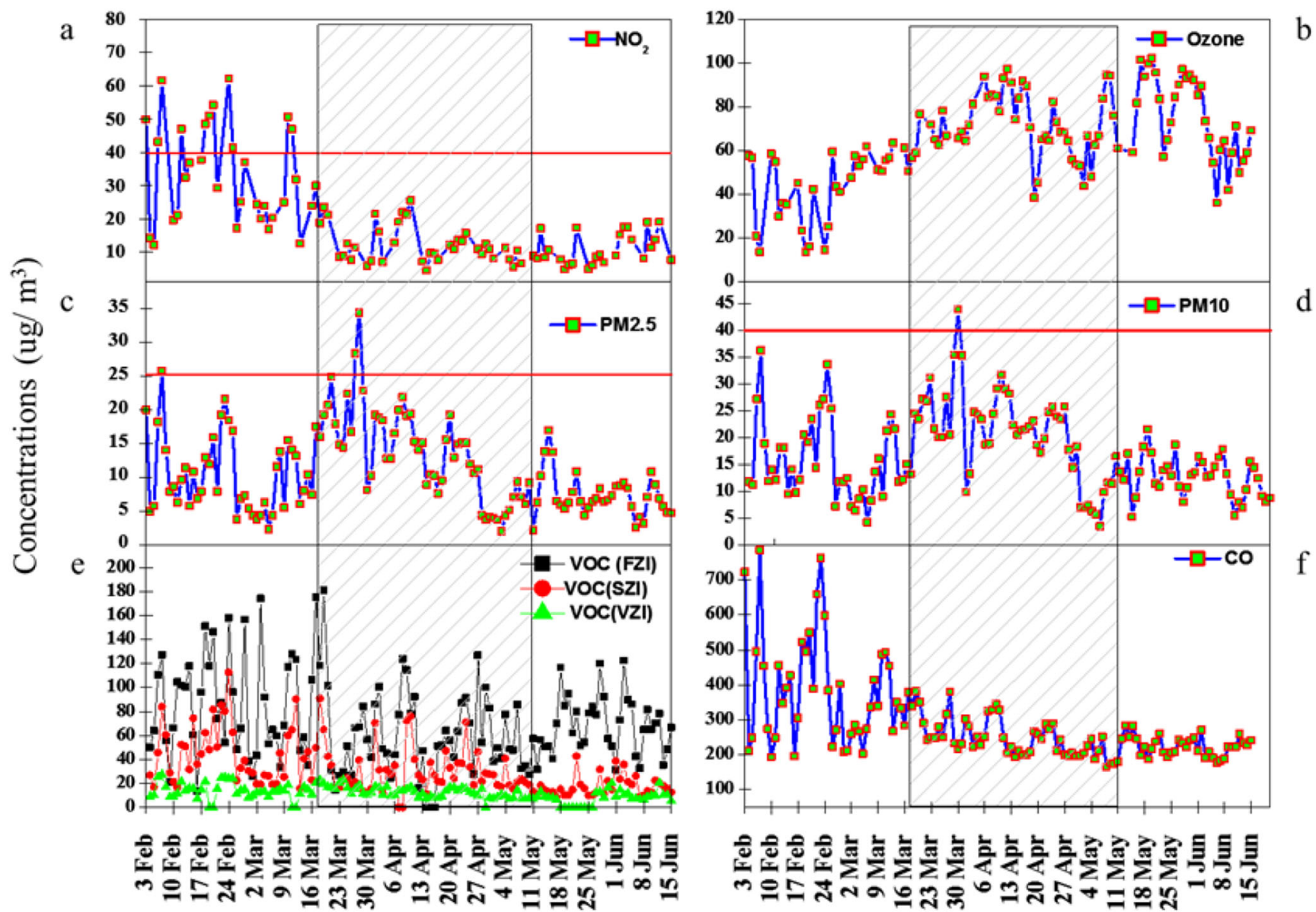

Fig. 5 Trend of average concentrations at Lyon Downtown for a $\mathrm{NO}_{2}$ (24 h average), b ozone ( $8 \mathrm{~h}$ average daily maxima), c PM2.5 (24 h average), d PM10(24 h average), e VOC FZI (Feyzin Zone Industriel), VOC SZI (Saint- Fons Zone Industriel), VOC VZI (Vernaison Zone Industriel), 10, 15, and $6 \mathrm{~km}$ from Lyon downtown (at South),

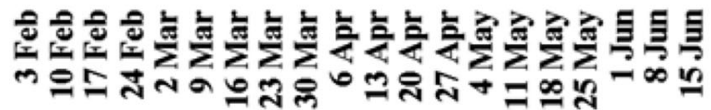

respectively, and $\mathbf{f} \mathrm{CO}$. Between 3rd Feb and 15th Jun, the horizontal red lines for NO2, PM2.5, and PM10 indicate the limit values; for the other pollutants, there is no exceedance of limit values (the dense area represented lockdown period) 
However, a slight upward trend has emerged since the start of progressive removal of lockdown from May 11 th. It should be noted that the $\mathrm{NO}_{2}$ level dropped since February 23th, due to decreased road densities a week before strict lockdown (Fig. 5a). The $\mathrm{O}_{3}$ levels have increased steadily since February 23th and remain almost stable during the lockdown (Fig. 5b). However, a significant decrease in ozone was observed after April 18th due to the consecutive rainy days and moderate sunshine (Fig. $6 \mathrm{~b}$ and d). The atmospheric oxidation of VOCs can represent an important source of ozone in Lyon since the VOC levels remained almost stable during lockdown (Fig. 5e) (Zhang et al. 2020).

Meteorological conditions such as solar radiation, humidity, temperature, sunshine, rainfall, and wind speed can affect ozone formation through modulating the rate of chemical kinetics reaction, the partitioning of reaction pathways, and efficiency of dry and humid deposition (Lu et al. 2019a, b). Lyon region is very sunny and characterized by a hot continental climate, which is more sensitive to ozone pollution. Solar radiation has increased regularly from 3rd February to 15th June (Fig. 5c), which can lead to an increase of atmospheric photochemistry and ozone formation. Figure 5 a shows a continuous increase in temperature, which can lead to an increase in natural emissions of BVOC, in particular isoprene (Fig. S6). The atmospheric oxidation of BVOC contributes to the formation of ozone (Allison 2020). On other hand, despite the reduction in the carbon monoxide mass concentration
(Fig. 5f), the $\mathrm{O}_{3}$ formation may be influenced by $\mathrm{CO}$ reactivities, because under low NOx level, ozone depletion can occur; however, under high NOx level, $\mathrm{CO}$ can contribute to ozone formation according to the reaction mechanism depicted in Table 3.

Figures $5 \mathrm{c}$ and $\mathrm{d}$ show the evolution of $\mathrm{PM}_{10}$ and $\mathrm{PM}_{2.5}$, respectively, in Lyon between 3rd February and 15th June. $\mathrm{PM}_{10}$ and $\mathrm{PM}_{2.5}$ present the same trend and show a continuous increase during the lockdown. However, this trend was perturbed by successive rainy days from 25th April (Fig. 6d), which removed all the suspended particles (Info climat 2020). The decrease of ozone, solar radiation, and the sunshine between 25th April and 11th May (Fig. 6 a, b, and c) can limit) can limit, and c) can limit, b, and c) can limit the formation of secondary particles resulting in the decrease of PM levels. Chen et al. (2020a, 2020b) show also an increase in PM during lockdown; they have found two pollution episodes with $\mathrm{PM}_{2.5}$ exceeding $100 \mu \mathrm{g} / \mathrm{m}^{3}$ in Shanghai, China.

\section{Air quality index change during lockdown in Lyon}

Air quality index (AQI) has been used in several cities around the world to quantify the presence of certain pollutants in ambient air. Their main purpose is to inform the public about air pollution and the associated potential health risk (Atmo 2020d). The AQI calculation is defined at the national level on the basis of regulatory thresholds (Table 4). Three

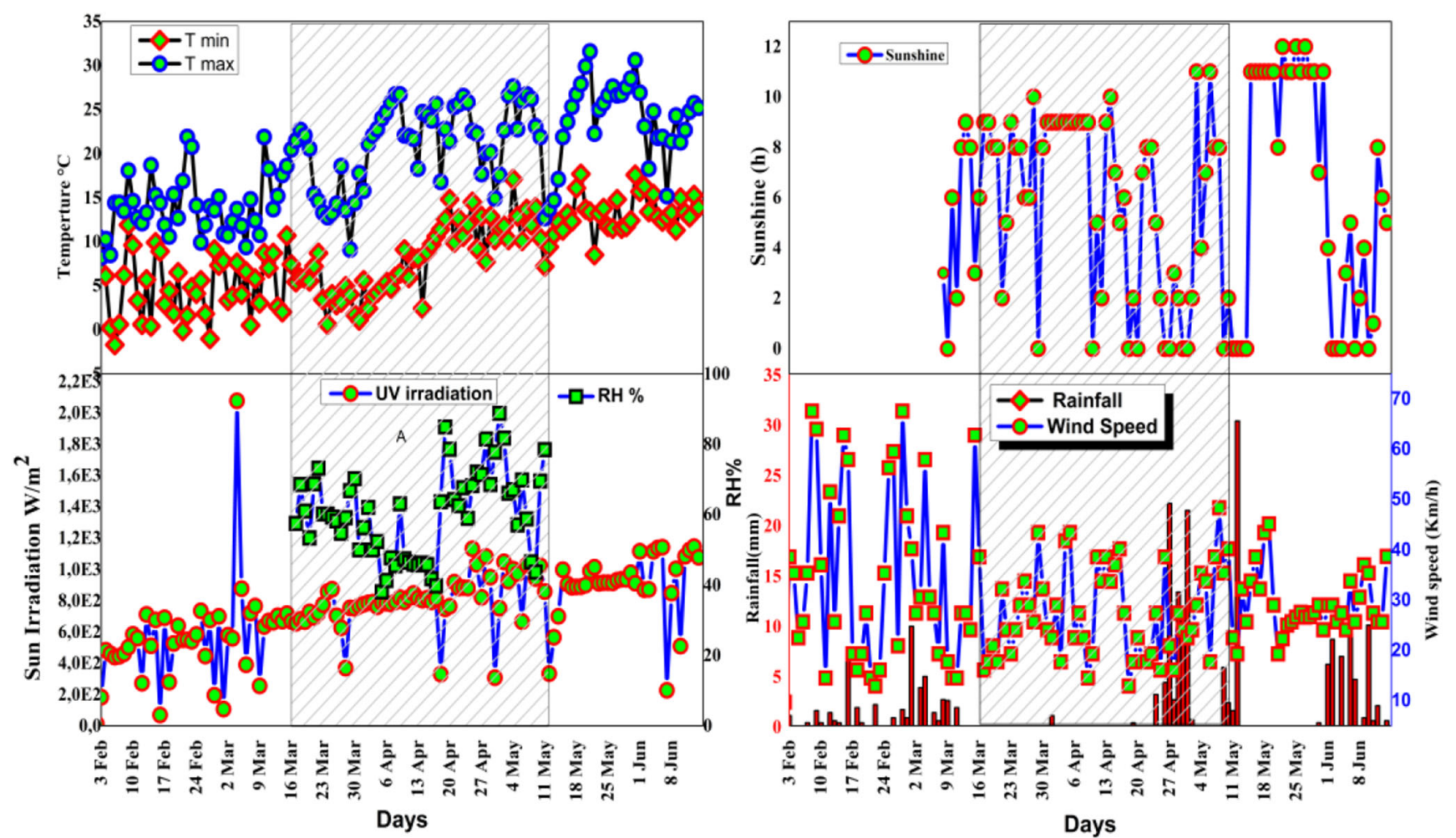

Fig. 6 Meteorological parameters pattern including temperature, humidity, rainfall, wind speed, sun radiation, and sunshine, at Lyon downtown between February 3rd and June 15th, 2020 (the dense area represented lockdown period) 
Table 3 Carbon monoxide (CO) reaction mechanism showing $\mathrm{O}_{3}$ depletion under low $\mathrm{NOx}$ level and $\mathrm{O}_{3}$ formation under high $\mathrm{NOx}$ level

\begin{tabular}{ll}
\hline Low NOx level (during lockdown) & High NOx level (before lockdown) \\
\hline $\mathrm{CO}+\mathrm{OH}+\mathrm{M} \geq \mathrm{CO}_{2}+\mathrm{H}$ & $\mathrm{CO}+\mathrm{OH}+\mathrm{M} \geq \mathrm{CO}_{2}+\mathrm{H}$ \\
$\mathrm{H}+\mathrm{O}_{2}+\mathrm{M} \geq \mathrm{HO}_{2}+\mathrm{M}$ & $\mathrm{H}+\mathrm{O}_{2}+\mathrm{M} \geq \mathrm{HO}+\mathrm{M}$ \\
$\mathrm{HO}_{2}+\mathrm{O}_{3} \geq \mathrm{OH}+2 \mathrm{O}_{2}$ & $\mathrm{HO}_{2}+\mathrm{NO} \geq \mathrm{OH}+\mathrm{NO}_{2}$ \\
$\mathrm{Net}: \mathrm{CO}+\mathrm{O}_{3} \geq \mathrm{CO}_{2}+\mathrm{O}_{2}$ & $\mathrm{NO}_{2}+\mathrm{hv} \geq \mathrm{NO}+\mathrm{O}$ \\
& $\mathrm{O}+\mathrm{O}_{2}+\mathrm{M} \geq \mathrm{O}_{3}+\mathrm{M}$ \\
& $\mathrm{NET}: \mathrm{CO}+2 \mathrm{O}_{2} \geq \mathrm{CO}_{2}+\mathrm{O}_{3}$
\end{tabular}

pollutants were considered for AQI estimation, including $\mathrm{NO}_{2}, \mathrm{O}_{3}$, and $\mathrm{PM}_{10}$. These species are considered as the main indicators of air pollution. For each of these pollutants, a subindex is determined using daily mass concentration between February 3rd and June 15th, the final index corresponding to the highest sub-index. The air quality sub-index associated with $\mathrm{O}_{3}, \mathrm{NO}_{2}$, and $\mathrm{PM}_{10}$ at Lyon downtown shows that $\mathrm{PM}_{10}$ represents the main pollutant and the AQI is often attached to the $\mathrm{PM}_{10}$ mass concentration (Fig. S7). In addition, the AQI of the region generally varies between good and moderate, which indicates that there is no possibility of affecting public health. Despite the decrease of $\mathrm{NO}_{2}$ level, the AQI level is not reduced during the lockdown due to a notable increase in PM. However, other studies have shown a drop in AQI; this decrease has been explained as a consequence of halting the human activities (Mahato and Ghosh 2020; Bao and Zhang 2020; He et al. 2020a, 2020b) (Table 3).

\section{Air pollution in 2020 vs 2019}

We have performed a comparison with data for main air pollution $\left(\mathrm{NO}_{2}, \mathrm{O}_{3}, \mathrm{PM}_{10}\right.$, and $\left.\mathrm{PM}_{2.5}\right)$ of previous year 2019 and this year 2020 over the same period (17th Mars to 11th May) corresponding to the lockdown period for six cities in the region (Lyon, Saint Etienne, Grenoble, Annecy, Gaillard, and Valence) (Fig. S8). The results show that for all the cities, the $\mathrm{NO}_{2}$ decreased whereas $\mathrm{O}_{3}$ and the particles $\left(\mathrm{PM}_{10}\right.$ and $\mathrm{PM}_{2.5}$ ) increased. The difference between the level of

Table 4 Correspondence grid for the index values with the thresholds of the inter-prefectural decree for the management of pollution episodes

\begin{tabular}{lllll}
\hline Categories & $\mathrm{AQI}$ & $\mathrm{PM}_{10}\left(\mu \mathrm{g} / \mathrm{m}^{3}\right)$ & $\mathrm{NO}_{2}\left(\mu \mathrm{g} / \mathrm{m}^{3}\right)$ & $\mathrm{O}_{3}\left(\mu \mathrm{g} / \mathrm{m}^{3}\right)$ \\
\hline Good & $0-50$ & 0 à 13 & $0-54$ & $0-54$ \\
Satisfactory & $51-100$ & $14-27$ & $55-109$ & $55-104$ \\
Moderate & $101-200$ & $28-41$ & $110-164$ & $105-149$ \\
Poor & $201-300$ & $42-64$ & $165-274$ & $150-209$ \\
Very poor & $301-400$ & $65-79$ & $275-399$ & $210-239$ \\
Severe & $401-500$ & $\geq 80$ & $\geq 400$ & $\geq 240$ \\
\hline
\end{tabular}

pollutants in 2019 and 2020 changes depending on each city; this can be explained by the meteorological conditions and the industrial activities of each zone and also the lockdown measures (strict or loose).

\section{Conclusion}

In order to assess the air quality status of Auvergne-RhôneAlpes during the lockdown period, we explored data related to atmospheric pollutants extracted from 79 air quality monitoring stations covering the whole region. The daily and hourly concentrations of air pollutants including $\mathrm{PM}_{2.5}, \mathrm{PM}_{10}$, $\mathrm{NOx}$ $\left(\mathrm{NO}_{2}\right.$ and $\mathrm{NO}$ ), $\mathrm{CO}, \mathrm{O}_{3}, \mathrm{SO}_{2}, \mathrm{VOC}$, and isoprene have been obtained from the online portal for air quality data dissemination.

The results revealed a substantial change in all studied atmospheric pollutants except the $\mathrm{VOC}$ and $\mathrm{SO}_{2}$ during the lockdown, as $\mathrm{NO}_{2}, \mathrm{NO}$, and $\mathrm{CO}$ have decreased, owing to restriction of road traffic. However, $\mathrm{O}_{3}$, PM2.5, and PM10 have increased during the lockdown. The increase in ozone is attributed to the decrease in its titration by NO because the flux of ozone depletion via a photochemical reaction involving NO decreased by $40 \%$. On the other hand, the reduction in ozone consumption by other gases is of anthropic origin. Moreover, weather conditions (temperature, solar radiation, $\mathrm{RH}$, sunshine) have favored the formation of ozone during the lockdown. Thus, the oxidation of VOC and BVOC also can contribute significantly to $\mathrm{O}_{3}$ and $\mathrm{PM}$ formation, because they have not been reduced during the lockdown. The AQI which represents good and moderate categories remains almost stable despite the decrease of NOx because $\mathrm{PM}$ and $\mathrm{O}_{3}$ increase. It is noted that $\mathrm{AQI}$ shows that $\mathrm{PM}_{10}$ is the main pollutant in this region.

Supplementary Information The online version contains supplementary material available at https://doi.org/10.1007/s11869-020-00965-w.

Acknowledgments We thank the Atmo Auvergne Rhône Alpes website for allowing us to use the data and for technical information provided by Mr. Sébastien WAITZ.

Data availability All the data used in this study are freely available on the Internet. Air quality data can be obtained through Atmo Auvergne Rhône Alpes website.

\section{References}

Agarwa A, Kaushik A, Kumar S, Mishra RK (2020) Comparative study on air quality status in Indian and Chinese cities before and during the COVID-19 lockdown period. Air Qual Atmos Health 13:11671178. https://doi.org/10.1007/s11869-020-00881-z

Allison LS (2020) Role of the terrestrial biosphere in atmospheric chemistry and climate. Acc Chem Res 7:1260-1268. https://doi.org/10. 1021/acs.accounts.0c00116 
Lucie Anzivino et Magali Venzac (2018) Diagnostic santé environnement des habitants de la Métropole de Lyon

(Atmo 2020a) Atmo-Auvergne-Rhône-Alpes online portal, for air quality data dissemination. 2020a. Available at https://www. atmoauvergnerhonealpes.fr/donnees/telecharger. Accessed 15 May 2020

(Atmo 2020b) Atmo-Auvergne-Rhône-Alpes online portal, Episode ozone. 2020b. Available at https://www.atmo-auvergnerhonealpes. fr/article/episode-ozone. Accessed 30 May 2020

(Atmo 2020c) Atmo-Auvergne-Rhône-Alpes online portal, pollution sources. $2020 \mathrm{c}$. Available at https://www.atmoauvergnerhonealpes.fr/article/sources-de-pollution. Accessed 20 June 2020

(Atmo 2020d) Atmo-Auvergne-Rhône-Alpes online portal, indices-dequalite-de-1'air. 2020e. Available at https://www.atmoauvergnerhonealpes.fr/article/indices-de-qualite-de-lair. Accessed 30 July 2020

Bao R, Zhang A (2020) Does lockdown reduce air pollution? Evidence from 44 cities in northern China. Sci Total Environ 731:139052. https://doi.org/10.1016/j.scitotenv.2020.139052

Bernard SS, Rolland P, Silue Y et al (2020) First cases of coronavirus disease 2019 (COVID-19) in France: surveillance, investigations and control measures, January 2020. Euro Surveill 25. https://doi. org/10.2807/1560-7917.ES.2020.25.6.2000094

Chauhan A, Singh RP (2020) Decline in PM2.5 concentrations over major cities around the world associated with COVID-19. Environ Res 187:109634. https://doi.org/10.1016/j.envres.2020.109634

Chen H, Huo J, Fu Q, Duan Y et al (2020a) Impact of quarantine measures on chemical compositions of PM2.5 during the COVID-19 epidemic in Shanghai, China. Sci Total Environ 743:140758. https://doi.org/10.1016/j.scitotenv.2020.140758

Chen L, Zhu J, Liao H, Yang Y, Yue X (2020b) Meteorological influences on PM2.5 and $\mathrm{O} 3$ trends and associated health burden since China's clean air actions. Sci Total Environ 744:140837. https://doi. org/10.1016/j.scitotenv.2020.140837

Chu B, Zhang S, Liu J, Ma Q, He H (2020) Significant concurrent decrease in PM2.5 and NO2 concentrations in China during COVID19 epidemic. J Environ Sci 99:346-353. https://doi.org/10.1016/j. jes.2020.06.031

Dantas G, Siciliano B, França BB, da Silva CM, Arbilla G (2020) The impact of COVID-19 partial lockdown on the air quality of the city of Rio de Janeiro, Brazil. Sci Total Environ 729:139085. https://doi. org/10.1016/j.scitotenv.2020.139085

European Commission, 2019. Air Quality Standards. Available at https:// ec.europa.eu/environment/air/quality/standards.htm. Accessed 06 June 2020

Fibois, 2018: Fibois. Agreste Auvergne-Rhône-Alpes, données 2018 IGN, données 2018. Available at https://www.fibois-aura.org/foret/ les-chiffres-cles-de-la-foret-en-auvergne-rhone-alpes/. Accessed 15 June 2020

Gautam S (2020) COVID-19: air pollution remains low as people stay at home. Air Qual Atmos Health 13:853-857. https://doi.org/10.1007/ s11869-020-00842-6

Gómez Martín JC, Gálvez O, Baeza-Romero MT, Ingham T, Plane JMC, Blitz MA (2013) On the mechanism of iodine oxide particle formation. Phys Chem Chem Phys 15:15612-15622. https://oi.org/10. 1039/c3cp51217g

He G, Pan Y, Tanaka T (2020a). The short-term impacts of COVID-19 lockdown on urban air pollution in China. Nat Sustain https://doi. org/10.1038/s41893-020-0581-y

He L, Zhang S, Hu J, Li Z, Zheng X, Cao Y, Xu G, Yan M, Wu Y et al (2020b) On-road emission measurements of reactive nitrogen compounds from heavy-duty diesel trucks in China. Environ Pollut 262: 114280. https://doi.org/10.1016/j.envpol.2020.114280

Huang M, Lin Y, Huang X, Liu X, Guo X, Hu C, Zhao W, Gu X, Fang L, Zhang W (2015) Experimental study of particulate products for aging of 1,3,5-trimethylbenzene secondary organic aerosol. Atmos Pollut Res 6:209-219. https://doi.org/10.5094/APR.2015.025

Info climat, 2020 : Station météorologique de Lyon-Bron. Available at https://www.infoclimat.fr/observations-meteo/temps-reel/lyonbron/07480.html. Accessed 20 May 2020

Kerimray A, Baimatova N, Ibragimova OP, Bukenov B, Kenessov B, Plotitsyn P, Karaca F (2020) Assessing air quality changes in large cities during COVID-19 lockdowns: the impacts of traffic-free urban conditions in Almaty, Kazakhstan. Sci Total Environ 730: 139179. https://doi.org/10.1016/j.scitotenv.2020.139179

Kourtchev I, Giorio C, Manninen A, Wilson E, Mahon B, Aalto J, Kajos M, Venables D, Ruuskanen T, Levula J, Loponen M, Connors S, Harris N, Zhao D, Kiendler-Scharr A, Mentel T, Rudich Y, Hallquist M, Doussin JF, Maenhaut W, Bäck J, Petäjä T, Wenger J, Kulmala M, Kalberer M (2016) Enhanced volatile organic compounds emissions and organic aerosol mass increase the oligomer content of atmospheric aerosols. Sci Rep 6:35038. https://doi.org/ 10.1038/srep35038

Lal P, Kumar A, Kumar S, Kumari S, Saikia P, Dayanandan A, Adhikari D, Khan ML (2020) The dark cloud with a silver lining: assessing the impact of the SARS COVID-19 pandemic on the global environment. Sci Total Environ 732:139297. https://doi.org/10.1016/j. scitotenv.2020.139297

Li X, Chee S, Hao J, Abbatt JPD, Jiang J, Smith JN (2018) Relative humidity effect on the formation of highly oxidized molecules and new particles during monoterpene oxidation. Atmos Chem Phys 19: 1555-1570. https://doi.org/10.5194/acp-2018-898

Lu K, Guo S, Tan Z, Wang H, Shang D, Liu Y, Li X, Wu Z, Hu M, Zhang Y (2019a) Exploring atmospheric free-radical chemistry in China: the self-cleansing capacity and the formation of secondary air pollution. Natl Sc Rev 6:579-594. https://doi.org/10.1093/nsr/nwy073

Lu X, Zhang L, Shen L (2019b) Meteorology and climate influences on tropospheric ozone: a review of natural sources, chemistry, and transport patterns. Curr Pollut Rep 5:238-260. https://doi.org/10. 1007/s40726-019-00118-3

Mahato S, Ghosh KG (2020) Short-term exposure to ambient air quality of the most polluted Indian cities due to lockdown amid SARSCoV-2. Environ Res 188:109835. https://doi.org/10.1016/j.envres. 2020.109835

Mahato S, Pal S, Ghosh KG (2020) Effect of lockdown amid COVID-19 pandemic on air quality of the megacity Delhi, India. Sci Total Environ 730:139086. https://doi.org/10.1016/j.scitotenv.2020. 139086

Mandal I, Pal S (2020) COVID-19 pandemic persuaded lockdown effects on environment over stone quarrying and crushing areas. Sci Total Environ 732:139281. https://doi.org/10.1016/j.scitotenv.2020. 139281

Ogen Y (2020) Assessing nitrogen dioxide (NO2) levels as a contributing factor to coronavirus (COVID-19) fatality. Sci Total Environ 726: 138605. https://doi.org/10.1016/j.scitotenv.2020.138605

Ortega AM, Hayes PL, Peng Z, Palm BB, Hu W, Day DA, Li R, Cubison MJ, Brune WH, Graus M, Warneke C, Gilman JB, Kuster WC, de Gouw J, Gutiérrez-Montes C, Jimenez JL (2016) Real-time measurements of secondary organic aerosol formation and aging from ambient air in an oxidation flow reactor in the Los Angeles area. Atmos Chem Phys 16:7411-7433. https://doi.org/10.5194/acp-167411-2016

Palm BB, Campuzano-Jost P, Ortega AM, Day DA, Kaser L, Jud W, Karl T, Hansel A, Hunter JF, Cross ES, Kroll JH, Peng Z, Brune WH, Jimenez JL (2016) In situ secondary organic aerosol formation from ambient pine forest air using an oxidation flow reactor. Atmos Chem Phys 16:2943-2970. https://doi.org/10.5194/acp-16-2943-2016

Pata UK (2020) How is COVID-19 affecting environmental pollution in US cities? Evidence from asymmetric Fourier causality test. Air Qual Atmos Health 13:1149-1155. https://doi.org/10.1007/ s11869-020-00877-9 
Peng Z, Day DA, Stark H, Li R, Lee-Taylor J, Palm BB, Brune WH, Jimenez JL (2015) HOx radical chemistry in oxidation flow reactors with low-pressure mercury lamps systematically examined by modeling. Atmos Meas Tech 8:4863-4890. https://doi.org/10. 5194/amt-8-4863-2015

Pullano G, Valdano E, Scarpa N, Rubrichi S, Colizza V (2020) Population mobility reductions during COVID-19 epidemic in France under lockdown (preprint). Infect Dis (except HIV/AIDS). https://doi.org/10.1101/2020.05.29.20097097

Saiz-Lopez A, Plane J (2004) Novel iodine chemistry in the marine boundary layer. Geophys Res Lett 2004(31):L04112. https://doi. org/10.1029/2003GL019215

Sbai SE, Farida B (2019a) Photochemical aging and secondary organic aerosols generated from limonene in an oxidation flow reactor. Environ Sci Pollut Res 26:18411-18420. https://doi.org/10.1007/ s11356-019-05012-5

Sbai SE, Farida B (2019b) Study of iodine oxide particles at the air/sea interface in the presence of surfactants and humic acid. Chem Chem Technol 13:341-346. https://doi.org/10.23939/chcht13.03.341

Sbai SE, Li C, Boreave A, Charbonnel N et al (2020) Atmospheric photochemistry and secondary aerosol formation of urban air in Lyon, France. 19:311-323. https://doi.org/10.1016/j.jes.2020.06.037

Shakoor A, Chen X, Farooq T.H., Farooq TH, Shahzad U, Ashraf F, Rehman A, Sahar N, Yan W (2020) Fluctuations in environmental pollutants and air quality during the lockdown in the USA and China: two sides of COVID-19 pandemic. Air Qual Atmos Health https://doi.org/10.1007/s11869-020-00888-6, 13, 1335, 1342

Sharma S, Zhang M, Gao J, Zhang H, Kota SH (2020) Effect of restricted emissions during COVID-19 on air quality in India. Sci Total Environ 728:138878. https://doi.org/10.1016/j.scitotenv.2020. 138878

Siciliano B, Dantas G, da Silva CM, Arbilla G (2020) Increased ozone levels during the COVID-19 lockdown: analysis for the city of Rio de Janeiro, Brazil. Sci Total Environ 737:139765. https://doi.org/10. 1016/j.scitotenv.2020.139765
Tobías A, Carnerero C, Reche C, Massagué J, Via M, Minguillón MC, Alastuey A, Querol X (2020) Changes in air quality during the lockdown in Barcelona (Spain) one month into the SARS-CoV-2 epidemic. Sci Total Environ 726:138540. https://doi.org/10.1016/j. scitotenv.2020.138540

WHO (World Health Organization) (2020) Transmission of SARS-CoV2: implications for infection prevention precautions. https://www. who.int/news-room/q-a-detail/q-a-how-is-covid-19-transmitted. Accessed 15 June 2020

Yao Y, Pan J, Liu Z, Meng X, Wang Weidong Kan H (2020) Temporal association between particulate matter pollution and case fatality rate of COVID-19 in Wuhan. Environ Res 189:109941. https:// doi.org/10.1016/j.envres.2020.109941

Zambrano-Monserrate MA, Ruano MA, Sanchez-Alcalde L (2020) Indirect effects of COVID-19 on the environment. Sci Total Environ 728:138813. https://doi.org/10.1016/j.scitotenv.2020. 138813

Zhang Y (2019) Dynamic effect analysis of meteorological conditions on air pollution: a case study from Beijing. Sci Total Environ 684:178 185. https://doi.org/10.1016/j.scitotenv.2019.05.360

Zhang Y, Li C, Yan Q, Han S, Zhao Q, Yang L, Liu Y, Zhang R (2020) Typical industrial sector-based volatile organic compounds source profiles and ozone formation potentials in Zhengzhou, China. Atmos Pollut Res 11:841-850. https://doi.org/10.1016/j.apr.2020. 01.012

Zhu Y, Xie J, Huang F, Cao L (2020) The mediating effect of air quality on the association between human mobility and COVID-19 infection in China. Environ Res 189:109911. https://doi.org/10.1016/j. envres.2020.109911

Publisher's note Springer Nature remains neutral with regard to jurisdictional claims in published maps and institutional affiliations. 